\title{
Duration of works, flight hours, and blood pressure related to noise-induced hearing loss among Indonesian Air Force helicopter pilots
}

\author{
Kholidah Hanum ${ }^{*}$, Hari Haksono*, Bastaman Basuki ${ }^{f}$
}

\begin{abstract}
Abstrak
Pilot helikopter terpajan bising tinggi dan beberapa faktor lainnya yang mempertinggi risiko tuli akibat bisisng (TAB). Oleh karena itu perlu diteliti beberapa faktor yang berkaitan dengan TAB. Pada penelitian ini yang memakai desain nest case-control. data diekstrak dari rekam medis penerbang helikopter yang melakukan indoktrinasi latihan aerofisiologi (ILA) antara tahun 1980 sampai Maret 2004 di Lembaga Kesehatan Penerbangan dan Luar Angkasa Saryanto, Jakarta. Kasus ialah subjek pada audiogram mepunyai notch 40 dB atau lebih pada 4000 Hertz pada telinga kiri, kanan, atau keduanya. Kasus dipadankan dengan dua kontrol yang tidak mendaerita TAB sam,pai tahun 2004. Semua faktor risiko pada kasus dan kontrol dihitung berdasarkan keadaan kasus didiagnosis TAB. Pada penelitian diperoleh 187 rekam medis, dan diperoleh 32 kasus untuk dibandingkan dengan 64 kontrol. Pada model akhir terlihat bahwa TAB berkaitan dengan total lama kerja, jam terbang, dan tekanan darah. Subjek yang 500 jam terbang atau lebih dibandingkan dengan yang dari dari 500 jam terbang mempunyai risiko moderat 2.5 menderita TAB [odds ratio suaian $\left(O R_{a}\right)=2,50$; 95\% interval kepercayaan $(C I)=0,66-9,29 ; p=0,180]$. Subjek dengan masa kerja 11-24 tahun risiko moderat 2.5 menderita TAB 2,7 kali $\left(O R_{a}=2,71 ; 95 \% C I=0,90-8,10 ; p=0,075\right)$. Selanjutnya, subjek prahipertensi dan hipertensi stage 1 dibandingkan subjek dengan tekanan darah normal juga mempunyai tren moderat kenaikan risiko TAB. Disimpulkan bahwa total jam terbang 500 jam atau lebih, total kerja 11-24 tahun, atau prehipertension dan and hipertensi stage 1 mempertinggi risiko TAB. (Med J Indones 2006; 15:185-90)
\end{abstract}

\begin{abstract}
Helicopter pilots exposed to high intensity noise and other risk factors had increased risk to be noise-induced hearing loss (NIHL). Therefore, it is beneficial to study several risk factors related to NIHL. This study was a nested case-control. Data was extracted from available medical records among helicopter pilots who performed routine aerophysiology training indoctrination (ILA) during 1980 through March 2004 at Saryanto Institute for Aviation and Aerospace Medicine (Lakespra), Jakarta. Case was those who had audiogram with a notch of $40 \mathrm{~dB}$ or more and of $4000 \mathrm{Hertz}$ on one site or bilateral ears. A case was matched by two controls who free from NIHL up to 2004. All risk factors for cases and controls were counted as of reference date of cases diagnosed. There were 187 medical records available for this study. A number of 32 cases and 64 controls were identified. The final model reveals that NIHL was related to total duration of works, flight hours, and blood pressure. Those who had 500 hours or more than less 500 hours had a moderate increased risk for 2.5 to be NIHL [Adjusted odds ratio $\left(O R_{a}\right)=2.50 ; 95 \%$ confidence intervals $(C I)=0.66-9.29 ; p=0.180$ ]. Those who had total duration works 11-24 years had a moderate increased to be NIHL for 2.7 times $\left(O R_{a}=2.71 ; 95 \%\right.$ CI=0.90-8.10; $p=0.075)$. Furthermore, prehypertension and hypertension stage 1 subjects than normal blood pressure had moderate trend increased risk to be NIHL. In conclusion total flight hours for 500 hours or more, total duration works 11-24 years, or prehypertension and hypertension stage 1 increased risk NIHL. (Med J Indones 2006; 15:185-90)
\end{abstract}

Keywords: noise induced hearing loss, flight hours, working duration, blood pressure

Good hearing is needed in order to optimize the communication for aircrews in order to prevent fatal impact to aviation safety. Error in voice transmission

\footnotetext{
* Saryanto Institute for Aviation and Aerospace Medicine, Jakarta, Indonesia

${ }^{f}$ Department of Community Medicine, Faculty of Medicine, University of Indonesia, Jakarta, Indonesia
}

caused accident and incident during a military operation in 1995 in Bosnia due to the lack of voice communication. ${ }^{1}$

Noise-induced hearing loss (NIHL) is a kind of sensory nerve hearing loss that is most often found among pilots in developing as well as developed countries. The helicopter has unique acoustic problems associated with NIHL. The NIHL related to a variety 
of factors, among others, aging process age, duration of work, total flight hours, type of aircraft, and aircraft noise exposure. ${ }^{2,3}$ Previous study in 1994 , with the Indonesian Air Force and Army helicopter pilots and air mechanics subjects reveals that NIHL was related to occupation (pilot or air technician), degree of noise, and total flight hours. ${ }^{4}$ Based on these findings, the Indonesian Air Force has made some efforts in order to lower the risk of NIHL.

The objective of this study is to identify some more risk factors in particular among helicopter pilot who still actively worked in 2004

\section{METHODS}

The design of this study was nested case-control. Subjects consisted of helicopter pilots who started work from 1980 to 2002 who have been working helicopter pilots until March 2004. The data were extracted from medical records at Saryanto Institute for Aviation and Aerospace Medicine (Lakespra) Jakarta among pilots in April 2004.

The case was the Indonesian Air Force helicopter pilot who suffered from NIHL at the hearing threshold $40 \mathrm{~dB}$ or less at the frequency of $4000 \mathrm{~Hz} .^{5}$ Control was the helicopter pilot who were never known to suffer from NIHL based on audiogram check up results as of March 2004. Each case was matched by two controls by the year case diagnosed NIHL. The pilots who had or suffered from non NIHL or head injury were excluded.

In this study, all risk factors for cases were counted as of reference date of cases diagnosed, and risk factors for the control counted as of the reference date of his matched case was diagnosed.

The work duration, total flight hours, and the average flight hours were calculated since the case flew the helicopter for the first time until the case suffered from NIHL. Meanwhile for the control, they were calculated since the control flew the helicopter for the first time until the reference date of his case. The total flight hours were calculated since the pilot flew the helicopter for the first time until he suffered from NIHL or until reference date of his case. For the analysis purpose, it was divided into 120-999 hours, 1000-2999 hours, and 3000-5300 hours.
The period of work was a year number when he started work until the case was diagnosed NIHL (for the case). On the other hand, for control, it was calculated since he started to work until the year his reference date of his case was diagnosed NIHL. For the analysis purpose it was divided into 0-10 year and 11-24 year period of work. The age of the beginning of work was the age when he started to fly the helicopter for the first time. For analysis purpose it was divided into 21-24 years and 25-26 years.

The year of beginning of work was the year when the subject started to fly helicopter. For the analysis purpose it was divided into 1980-1990 and 1991-2000.

The total flight hours were the total flight hours when he started to fly helicopter until a subject was diagnosed NIHL (for the case), and for the matched control it was until the year when his reference case was diagnosed NIHL. For analysis purpose, they were divided into 120-999 hours, 1000-2999 hours, and 3000-5300 hours.

The average flight hours per year were the total flight hours divided by the period of work in a year. For analysis purpose, they were divided into 40-299 hours and 300-734 hours.

Helicopter noise was based on the size and weight of the helicopter rotor (personal communication with the health office of Indonesian Air Force). Helicopters with low noise were Bolcow and Bell. Helicopter with medium or high noise were Twinpack and Superpuma.

Acoustic trauma was hearing loss caused by a very loud sound or blast. Diabetes mellitus (DM) was defined as the glucose after fasting $126 \mathrm{mg} / \mathrm{dl}$ or more based on Indonesia Consensus on DM management in Indonesia. Hypercholesterolemia was the blood cholesterol higher than $200 \mathrm{mg} / \mathrm{dl}^{6}$

The use of ototoxic substance or drugs defined when the subject was taking drugs such as group of aminoglycocide (streptomycine, neomycine, kanamycine, amycacine, tobramycine, gentamycine and nethylmycine), other groups of antibiotic (vancomycine, erytromycine and azytomycine), diuretic, salysilate (aspirin) and anti-malaria drugs (Quinine) with the period of 5 days to 14 days according to the related drugs. For the analysis purpose, it was divided into yes/no.

Blood pressure classification based on National Heart, Lung, and Blood Institute (USA): The seventh report 
of the joint national commitee on prevention, detection, evaluation, and treatment of high blood pressure. The classification was: normal blood pressure $=$ systolic blood pressure was less than $120 \mathrm{mmHg}$ and diastolic blood pressure was less than $80 \mathrm{mmHg}$; prehypertension $=$ systolic blood pressure was $120-139$ $\mathrm{mmHg}$ or diastolic blood pressure was $80-89 \mathrm{mmHg}$; stage 1 hypertension = systolic blood pressure was 140-159 mmHg or diastolic blood pressure was 90-99 $\mathrm{mmHg}$; stage 2 hypertension was systolic $160 \mathrm{mmHg}$ or more, or diastolic blood pressure was $100 \mathrm{mmHg}$ or more. ${ }^{7}$

A risk factor to NIHL risk was calculated by the odds ratio with $95 \%$ confidence intervals. If on univariate analysis the value $\mathrm{p}$ ranged from 0.05 to 0.25 , the pertinent deserve to be considered as potential confounding factor which can be considered to be included in multivariate analysis to develop final models. ${ }^{8}$ The final model constructed by stepwise method using Stata program version 6.0. ${ }^{9}$

This study received ethical clearance from the Board of Post Graduate Examiners and Management of the
Department of Community Medicine of the University of Indonesia. All subject identifications were treated confidentially in order prevent harm for the subjects.

\section{RESULTS}

A number of 187 medical records of the helicopter pilots were available for this study. We identified 32 NIHL cases and 64 subjects who did not suffer from NIHL. The subjects aged from 22 years to 48 years. The shortest subject's period of work where NIHL occurred is two years and longest is 23 years. Based on the diagnosis year of NIHL, most cases of NIHL occurred in 1997 and the least cases occurred in 2003.

Table 1 shows that those who aged 30 years or more than aged 22-29 years upon diagnosis, year of entering work during period of 1991-2000 than 19801990, middle than primary officer more likely had increased risk to be NIHL. On the other hand, NIHL cases and controls were similarly distributed with regard to age of entering work, average flight hours per-year, and type of helicopter that was flown.

Table 1. Age and year of starting work, rank, average of flight, helicopter type and risk of noise-induced hearing loss (NIHL)

\begin{tabular}{|c|c|c|c|c|c|c|c|}
\hline & \multicolumn{4}{|c|}{ Hearing } & \multirow{3}{*}{$\begin{array}{l}\text { Crude odds } \\
\text { ratio }\end{array}$} & \multirow{3}{*}{$\begin{array}{l}95 \% \text { confidence } \\
\text { intervals }\end{array}$} & \multirow{3}{*}{$\mathrm{p}$} \\
\hline & \multicolumn{2}{|c|}{$\begin{array}{l}\text { Normal } \\
(\mathrm{N}=64)\end{array}$} & \multicolumn{2}{|c|}{$\begin{array}{l}\text { NIHL } \\
(\mathrm{N}=32)\end{array}$} & & & \\
\hline & $\mathrm{n}$ & $\%$ & $\mathrm{n}$ & $\%$ & & & \\
\hline \multicolumn{8}{|l|}{ Age on diagnosed } \\
\hline 22-29 years & 38 & 59.4 & 8 & 25.0 & 1.00 & Reference & \\
\hline $30-34$ years & 11 & 17.2 & 7 & 21.9 & 3.02 & $0.90-10.20$ & 0.075 \\
\hline $35-48$ years & 15 & 23.4 & 17 & 53.1 & 5.38 & $1.92-15.10$ & 0.001 \\
\hline \multicolumn{8}{|c|}{ Age of starting work } \\
\hline 21-24 years & 59 & 92.2 & 27 & 84.4 & 1.00 & Reference & \\
\hline 25-26 years & 5 & 7.8 & 5 & 15.6 & 2.19 & $0.58-8.18$ & 0.246 \\
\hline \multicolumn{8}{|c|}{ Year of entering work } \\
\hline $1980-1990$ & 27 & 42.2 & 23 & 71.9 & 1.00 & Reference & \\
\hline $1991-2000$ & 37 & 57.8 & 9 & 28.1 & 0.29 & $0.11-0.71$ & 0.007 \\
\hline \multicolumn{8}{|l|}{ Rank } \\
\hline Primary officer & 49 & 76.6 & 16 & 50.0 & 1.00 & Reference & \\
\hline Midle officer & 15 & 23.4 & 16 & 50.0 & 3.27 & $1.32-8.06$ & 0.010 \\
\hline \multicolumn{8}{|c|}{$\begin{array}{l}\text { Average of flight hours } \\
\text { per year }\end{array}$} \\
\hline $40-299$ jam & 58 & 93.5 & 30 & 93.8 & 1.00 & Reference & \\
\hline 300-734 jam & 4 & 6.5 & 2 & 6.3 & 0.98 & $0.17-5.67$ & 0.985 \\
\hline \multicolumn{8}{|c|}{ Noice of helicopter } \\
\hline Low & 24 & 37.5 & 15 & 46.9 & 1.00 & Reference & \\
\hline Moderate & 40 & 62.5 & 17 & 53.1 & 0.68 & $0.29-1.61$ & 0.379 \\
\hline
\end{tabular}


Table 2 shows that the risk related to acoustic trauma, $\mathrm{DM}$, the use of drugs or ototoxic substance against malaria could not be calculated due to there was no subject who ever suffered from that kind of disease or condition. The cholesterol level was noted not to be correlated with the risk of NIHL.

The final model as shown on Table 3, the risk factors related to NIHL were total flight hours, duration work, and the classification of blood pressure. In term of duration of work, those who had duration of work for 11-24 years than less than 10 years had increased risk to be NIHL for 4.3 times. Meanwhile, in term of blood pressure classification, a subject with prehypertension or stage 1 hypertension has a tendency of moderate risk increased risk to be NIHL.

Table 2. Some of laboratory and clinical findings and risk of noise-induced hearing loss (NIHL)

\begin{tabular}{|c|c|c|c|c|c|c|c|}
\hline & \multicolumn{4}{|c|}{ Hearing } & \multirow{3}{*}{$\begin{array}{l}\text { Cude odds } \\
\quad \text { ratio }\end{array}$} & \multirow{3}{*}{$\begin{array}{l}95 \% \text { confidence } \\
\text { intervals }\end{array}$} & \multirow{3}{*}{$\mathrm{P}$} \\
\hline & \multicolumn{2}{|c|}{$\begin{array}{l}\text { Normal } \\
(\mathrm{N}=64)\end{array}$} & \multicolumn{2}{|c|}{$\begin{array}{c}\text { NIHL } \\
(\mathrm{N}=32)\end{array}$} & & & \\
\hline & $\mathrm{n}$ & $\%$ & $\mathrm{n}$ & $\%$ & & & \\
\hline \multicolumn{8}{|l|}{ Acustic trauma } \\
\hline Never & 64 & 100 & 20 & 62.5 & & & \\
\hline Ever & 0 & 0 & 12 & 37.5 & $\mathrm{n} / \mathrm{a}$ & & \\
\hline \multicolumn{8}{|l|}{ Diabetes melitus } \\
\hline Never & 62 & 96.9 & 32 & 100 & $\mathrm{n} / \mathrm{a}$ & & \\
\hline Suspect & 2 & 3.1 & 0 & 0 & & & \\
\hline \multicolumn{8}{|l|}{ Cholesterol } \\
\hline Normal & 33 & 51.6 & 18 & 56.3 & 1.00 & Reference & \\
\hline Hypercholesterol & 31 & 48.4 & 14 & 43.8 & 0.82 & $0.35-1.94$ & 0.665 \\
\hline \multicolumn{8}{|c|}{ Ever ototoxsic drug } \\
\hline Never & 64 & 100 & 30 & 93.8 & $\mathrm{n} / \mathrm{a}$ & & \\
\hline Ever & 0 & 0 & 2 & 6.3 & & & \\
\hline
\end{tabular}

Remark:: n/a = not applicable

Tabel 3. Relationship bertween total working hour, duration of working, blood tension clasification and risk of noise-induced hearing loss (NIHL)

\begin{tabular}{|c|c|c|c|c|c|c|c|}
\hline & \multicolumn{4}{|c|}{ Hearing } & \multirow{3}{*}{$\begin{array}{l}\text { Adjusted odds } \\
\text { rasio* }\end{array}$} & \multirow{3}{*}{$\begin{array}{l}95 \% \text { confidence } \\
\text { intervals }\end{array}$} & \multirow{3}{*}{$\mathrm{P}$} \\
\hline & \multicolumn{2}{|c|}{$\begin{array}{l}\text { Normal } \\
(\mathrm{N}=64)\end{array}$} & \multicolumn{2}{|c|}{$\begin{array}{c}\text { NIHL } \\
(\mathrm{N}=32)\end{array}$} & & & \\
\hline & $\mathrm{n}$ & $\%$ & $\mathrm{n}$ & $\%$ & & & \\
\hline \multicolumn{8}{|l|}{ Total flight hours } \\
\hline $120-499$ hours & 28 & 43.8 & 5 & 15.6 & 1.00 & Reference & \\
\hline $500-5300$ hours & 36 & 56.2 & 27 & 84.4 & 2.47 & $0.66-9.29$ & 0.180 \\
\hline \multicolumn{8}{|l|}{ Duration of work } \\
\hline $0-10$ years & 46 & 71.9 & 12 & 37.5 & 1.00 & Reference & \\
\hline $11-24$ years & 18 & 28.1 & 20 & 62.5 & 2.71 & $0.90-8.10$ & 0.075 \\
\hline \multicolumn{8}{|l|}{$\begin{array}{l}\text { Blood pressure } \\
\text { clasification }\end{array}$} \\
\hline Normal & 20 & 31.3 & 6 & 18.8 & 1.00 & Reference & \\
\hline Prehipertension & 37 & 57.8 & 22 & 68.8 & 1.94 & $0.64-5.93$ & 0.243 \\
\hline Stage 1 & 7 & 10.9 & 4 & 12.5 & 2.77 & $0.51-14.76$ & 0.233 \\
\hline
\end{tabular}

*Adjusted odd ratios adjusted each others risk factors listed on this table 


\section{DISCUSSIONS}

We have some limitation in this study, among others, seven subjects did not undergo the annual medical check up routinely, or some data in some medical records were not complete was missing, among others, total flight hours or triglycerides rate. Therefore these subjects were not included in the study.

In 1997 there was increased number of NIHL cases. This is because probably there were substantial military operations in East Timor (Timor Leste) and at other places (personal communication, Indonesian Air Forces).

This is in accordance with the other findings on noise exposure during Alpine helicopter rescue operations which noted that while the risk to air crew and patients should be limited to temporary threshold shifts the crew members are regularly exposed to equivalent noise levels of $>85 \mathrm{~dB}(\mathrm{~A})$ and, therefore, are at risk of permanent threshold shifts. Consequences for crew fitness to fly and for noise prevention. ${ }^{11}$

Although prehypertension and hypertension stage 1 did not significantly increase risk of NIHL, a moderate increased was noted. This moderate influence is probably due to the number of subjects was small, Therefore, it cannot prove significantly the influence of hypertension to NIHL. However, early prevention by controlling blood pressure must be taken in order to reduce NIHL and other diseases caused by hypertension. ${ }^{7}$ This finding needs further investigation with more subjects to assess the impact of noise exposure on blood pressure (BP) and cardiovascular disease as proposed by other paper on the Hypertension and Exposure to Noise near Airports (HYENA) project. ${ }^{12}$ Other previous study noted that often only hearing loss is thought of when one refers to occupational noise, but there may be other factors such as blood pressure. What is not clear, however, is whether noise contributes to changes in blood pressure. $^{13}$

Although the result of crude odds ratio of the risk factor such as aged upon diagnosis, year of entering work, age of entering work, ranks, total flight hours, and the period of work seemed to be related to the NIHL risk, during the final model they did not related to NIHL. This might be due to those risk factors are overcome by the more dominant ones, period of work and blood pressure. ${ }^{8}$
Previous study findings using the pilot and air mechanic subjects during the period of 1970-1994, it was revealed that the risk factors which increase the possibility of NIHL were the position (pilots or air technicians), helicopter noise, and the total flight hours. ${ }^{3}$ Meanwhile, in this study there were two risk factors which increase the possibility the NIHL. They were the period of work and blood pressure. These different findings may be caused by the subjects that were observed. They were just helicopter pilot without involving the air technician. The helicopter noise in this study had nothing to do with NIHL this is may be because the helicopter pilot were not exposed much enough to the helicopter noise. The air mechanics are much more exposed to the helicopter noise. They have to prepare the helicopter before take off. Meanwhile the pilot doesn't have to prepare or warm up the helicopter before take off. Besides, there was a difference in the period of exposure. In the previous study the exposure was from 1970-1994. ${ }^{4}$ Meanwhile in this study the exposure was from 1980-2004.

In this study we cannot prove any risk increase of NIHL related to the type of helicopter. This may be because the pilot were not expose enough to the helicopter noise or the pilot always wore earplug or earmuff or headset.

\section{CONCLUSIONS}

During the period of 1997 high frequency of military operation occurred, and it was noted increased number of NIHL among military helicopter pilots. Furthermore, those who had longer total flight hours duration of work, and higher blood pressure had increased risk to be NIHL. Therefore, helicopter pilots who had a longer period of work needs more special attention to identify and prevent possible health related effects, workplace monitoring, audiometry, and blood pressure screenings are essential to minimize the risk of NIHL and fatal impact to aviation safety

\section{Aknowledgment}

The authors thank the Commander of Lakespra and the Indonesia Air Force Health Commander In-chief for their permission to access medical records for this study. Furthermore, to persons in charge of medical records who cooperatively assisted this study. Lastly, to Dr. Soemardoko to review the earlier drafts of this manuscript that improved the final product. 


\section{REERENCES}

1. Wagstaff AS, Woxen OJ, Andersen HT. Effects of active noise reduction on noise levels at the tympanic membrane. Aviat Space Environ Med 1998;69:539-44.

2. Dobie RA. Noise-Induced Hearing Loss. In: Bailey BJ, editor. Head and neck surgery otolaryngology. Vol.2. Philadelphia. JB Lippincott Co. 1993. pp. 1782-92.

3. Bashiruddin J. Age, duration of work, noise and vibration in inducing hearing and balance impairments. Med $\mathrm{J}$ Indones 2004;14:101-6.

4. Zulhidzaan I. Faktor-faktor yang mempengaruhi gangguan pendengaran pada awak pesawat helikopter TNI AU dan TNI AD (tesis). Jakarta: Univ. Indonesia; 1995.

5. Soetirto I, Hendarmin H. Gangguan pendengaran (tuli). In: Soepardi EA, Iskandar N. Buku ajar ilmu kesehatan telinga hidung tenggorok kepala leher. Edisi kelima. Jakarta: Balai Penerbit FKUI; 2001. pp 9-21.

6. Perkumpulan Endokrinologi Indonesia. Konsensus pengelolaan Diabetes melitus di Indonesia. Jakarta: Perkumpulan; 1998.

7. National Heart, Lung, and Blood Institute (USA). The seventh report of the joint national commitee on prevention, detection, evaluation, and treatment of high blood pressure. Bethesda NIH Publication No. 03-5233; May 2003.

8. Hosmer DW, Lameshow S. Applied logistic regression. Ed 2. New York. A Wiley-Interscience publication; 2000.

9. Stata Corp. Stata Statistical Software: Release 6.0.Getting started with Stata for Windows. Texas: Stata Corporation; 1999D

10. Basuki B, Hoesni HM, Budiningsih S, Mardjono M, Samil RS, Sadli S. Panduan etik penelitian biomedis dan reproduksi manusia. Jakarta: Badan Koordinasi Keluarga Berencana Nasional; 1999.

11. Küpper TEAH, Steffgen J, Jansing P. Noise Exposure During Alpine Helicopter Rescue Operations. Ann Occup Hyg. 2004;48:475-81.

12. Jarup 1, Dudley M-L, Babisch W, Houthuijs D, Swart W, Pershagen G, et al. Hypertension and Exposure to Noise Near Airports (HYENA): Study Design and Noise Exposure Assessment. Environ Health Perspect. 2005;113:1473-8.

13. Penney PJ, Earl CE. Occupational noise and effects on blood pressure: exploring the relationship of hypertension and noise exposure in workers. AAOHN J. 2004;52:476-80. 